\title{
The Upward and Downward Spirals in China's Anti-Corruption Enforcement
}

\author{
Fu Hualing*
}

\section{Introduction}

China's fight against corruption appears to have reached a stalemate. The fluctuation in the number of corruption prosecution, which was a characteristic of the official statistics until the early $1990 \mathrm{~s},{ }^{1}$ has virtually vanished. Instead, one sees flat lines. Transparency International's corruption perceptions index (CPI) score on China remains flat; the number of disciplinary measures taken by the Chinese Communist Party (hereafter "CCP" or "the Party") against its members for misconduct in recent years has also leveled off; and the number of criminal prosecution on corruption charges actually has been declining steadily (see Chart 1 ). ${ }^{2}$

The stalemate is surprising given the ideological and organizational adaptation in the CCP's fight against corruption. Ideologically, the $\mathrm{CCP}$ has enhanced its anti-corruption rhetoric and appears more determined than ever to control the spread of corruption. Organizationally, the CCP has increased investment in the anti-corruption establishment and provided additional financial and human resources to anti-corruption institutions. The high profile prosecution of high ranking officials in recent years and the imposition of harsh sentencing, including execution, contrast sharply with the larger institutional inertia.

\footnotetext{
* Professor of Law, the University of Hong Kong. The author would like to thank the following persons for their valuable comments on the earlier versions of this paper: Pinky Choy, Michael Dowdle, Ting Gong, Li Ling, and Eva Pils.

${ }^{1}$ Melanie Manion, Corruption by Design: Building Clean Government in Mainland China and Hong Kong (Cambridge: Harvard University Press, 2004), 89; Ting Gong, The Politics of Corruption in Contemporary China: An Analysis of Policy Outcomes (Praeger, 1994); and Andrew Wedeman, "Anticorruption Campaigns and the Intensification of Corruption in China" (2005) 14(42) Journal of Contemporary China 93-107; and "The Intensification of Corruption in China" (2004) 180 The China Quarterly 895-921.

2 Andrew Wedeman, "Win, lose, or draw? China's quarter century war on corruption" (2008) 49 Crime, Law and Social Change 7-26.
} 
Chart 1: Corruption Cases Filed by the Procuracy, Disciplinary Cases Handled by the Discipline Inspection \& Supervision Organs, and China's CPI Score (1990-2010) ${ }^{3}$

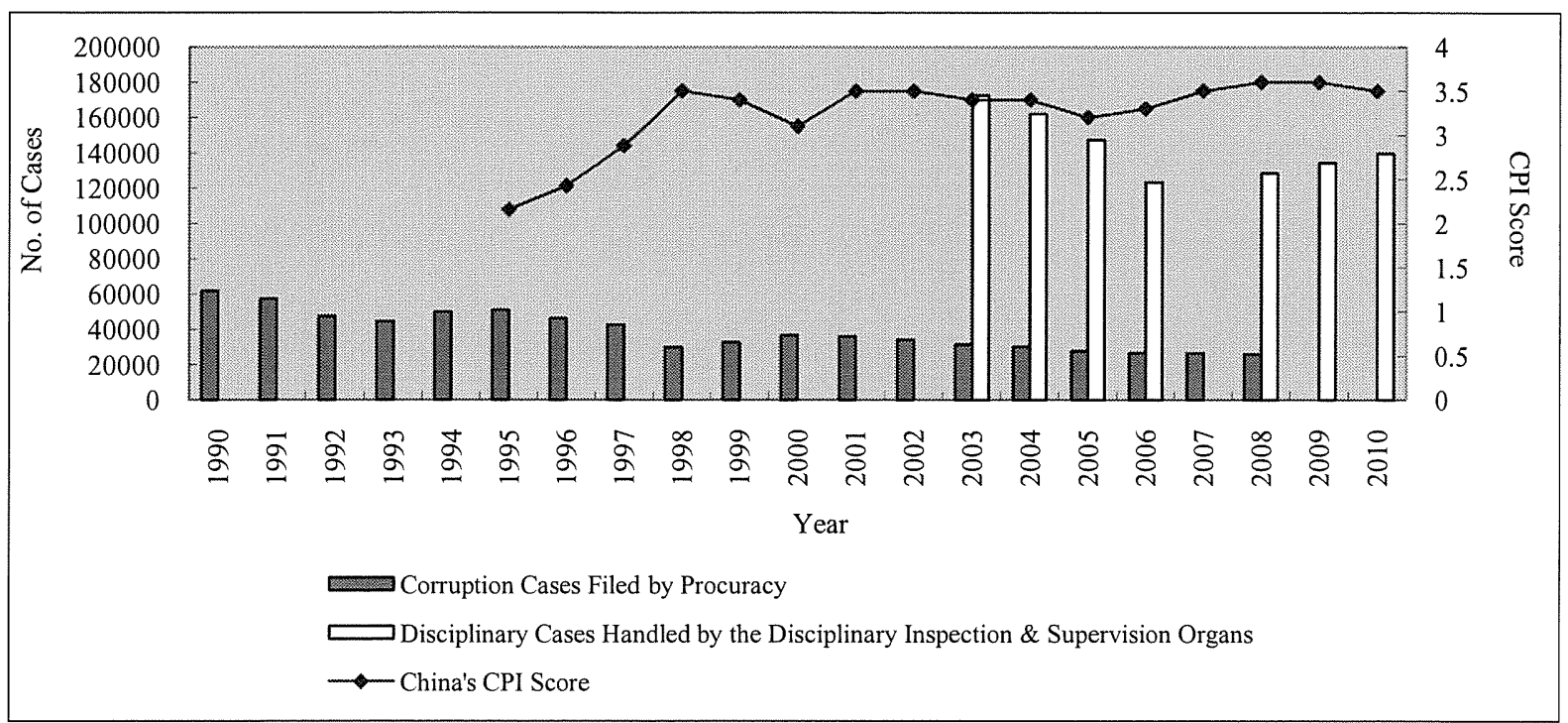

How to explain the apparent contradiction? Central to this question is the capacity of the CCP to curb the further entrenchment of corruption in the political system and to rein in officials who conspire to make personal gains. Given the politically disruptive and disintegrative nature of corruption, the litmus test for the CCP to remain in power is its willingness and ability to reverse the trend of corruption. But is China trapped in corruption?

There are two schools of thought. The "trap" school advances a collapsing thesis, arguing that corruption in China has become increasingly predatory and destructive, that corruption is entrenched, further institutionalized, and has developed a life of its own within the political system; that a large number of CCP officials are conspiring with each other and are unconstrained in enriching themselves; and that the CCP at the end will be forced to tolerate corruption in exchange for political loyalty and support. ${ }^{4}$ In sum, corruption is spreading, entrenching, and reaching the top echelon of the political power, and China will not be able to bring itself out of a vicious cycle of political corruption without fundamental political changes.

The opposing school of thought, the "gap" thesis, recognizes the seriousness of corruption in China, nevertheless believes in the political will and capacity of the CCP in containing, if not controlling, corruption through further institutional adaptation and renovation. There may be a

\footnotetext{
${ }^{3}$ Sources: Zhongguo Falü Nianjian [China Law Yearbook] (Beijing: Press of China Law Yearbook, 1991-2009); "Work Reports of the Central Committee of Disciplinary Inspection" (2004-2007; 2009-2011), available at Zhongguo Gongchandang Xinwen Wang [News of the Chinese Communist Party], <http://cpc.people.com.cn/GB/64162/106101/index.html> (Visited on 16 April 2011); "Corruption Perceptions Index", Transparency International, <http://www.transparency.org/policy_research/surveys_indices/cpi> (Visited on 16 April 2011).

${ }^{4}$ Minxin Pei, “Will China become another Indonesia?" (1999) 116 Foreign Policy 94-109.
} 
wide gap between legal and political norms and practices, but this gap can be effectively narrowed through enhanced disciplinary action and institutional innovation. From "auditing storms" to open government information, from the rule of law reform to media supervision, and from institutional building to periodical crackdowns, the CCP has not stopped creating and refining mechanisms that may tackle corruption at different levels and that produce some impact on the fight against corruption. ${ }^{5}$

This paper examines the two contrasting theses from the perspective of anti-corruption investigation. Consistent with the "gap" thesis, the CCP is taking a hands-on approach in tackling corruption and appears determined to clamp down hard on corruption, as demonstrated by the increase in prosecution of large-scaled corruption cases involving top CCP officials and the institutional renovation, though limited and piecemeal. However, consistent with the "trap" thesis, it is clear that the anti-corruption action is taken largely by the CCP's anti-corruption central authority, the Central Committee of Disciplinary Inspection (CCDI) and the CCDI takes direct action because local anti-corruption authorities are unable and unwilling to play an effective role. Facing the collective and syndicated nature of corruption, the local anti-corruption mechanism is retreating if not collapsing, leaving the Central Authorities the lone fighter against corruption.

This paper has five parts. Following this Introduction, Part II introduces the anti-corruption institutional framework in China with a focus on the importance of the disciplinary inspection committees within the CCP. The political disciplinary institution, the CCDI and the local disciplinary inspection committees, and anti-corruption legal institutions (i.e. the procuratorates) co-existed in the $1980 \mathrm{~s}$, both cooperating and competing with each other. But the political mechanism effectively absorbed the legal mechanism in 1992 and has become the primary anticorruption authority, marginalizing and incorporating the legal institutions. After discussing the relationship between the political, legal and administrative processes, Part II takes a further look at the internal disciplinary regime and provides a summary of the core features of that regime.

Following a critical examination of the disciplinary mechanism, the paper advances the thesis of two spirals in China's fight against corruption. Part III explains an upward spiral showing an increasingly hands-on approach by the CCDI in anti-corruption investigation. An investigation of major corruption is now impossible without the CCDI, partly because of the involvement of high-ranking officials over whom the CCDI has exclusive jurisdiction and partly because of the weakening capacity of local and regional anti-corruption institutions in taking effective actions against the increasingly syndicated nature of corruption.

\footnotetext{
${ }^{5}$ Dali L Yang, Remaking the Chinese Leviathan: Market Transition and the Politics of Governance in China (Stanford, Calif:: Stanford University Press, 2004); Jun Ma and Xing Ni, "Toward a clean government in China: Does the budget reform provide a hope" (2008) 49 Crime, Law and Social Change 119-138. For a critical reflection of the debate, see Jacques deLisle, "Traps, Gaps and Law: Prospects and Challenges for China's Reform," in Is China Trapped in Transition? Implications for Future Reforms (Oxford: Oxford Foundation for Law, Justice and Society, 2007).
} 
Part IV explains a downward spiral, showing the declining functionality of regional, and especial local, anti-corruption bodies including a lax enforcement of political and legal norms and lenient treatment that CCP officials receive even after convictions. Part V concludes the paper by discussing the implications of the upward and downward spirals to China's future political development.

\section{The Party's Disciplinary Inspection Mechanism}

\section{The Party and the Marginalization of Law}

Corruption is committed by state functionaries abusing their power for personal gain. Until recently when the offence was extended to the private sector, corruption had been limited to the public sector and was mostly perpetrated by members of the CCP. The CCP, as the constitutionally entrenched ruling party in China, monopolizes state power and, not surprisingly, its members occupy important positions in state institutions. Corruption within the CCP and the state therefore largely overlap.

The CCP is a Leninist Party, with a well-established disciplinary mechanism designed to punish its delinquent members. ${ }^{6}$ Legal institutions, on the other hand, have traditionally been weak and marginal under China's one party rule. While the legal reform in China since the late 1970s may have witnessed the reemergence of a legal system which is functioning and effective in civil and commercial matters, the CCP is in direct control over matters of political significance, especially those concerning the direct interest of the Party, including corruption perpetrated by its members.

Disciplinary inspection is a key component within the structure of the CCP. ${ }^{7}$ The CCP sets up a Committee at each level of the government, and within each local CCP Committee, there is a standing committee, called the "disciplinary inspection committee" (CDI), to be in charge of disciplinary matters against CCP members. A CDI is also accountable to both the CCP Committee at the same level and to the CDI at the next higher level. The executive government also created a supervision system to discipline civil servants. However, since most of the civil servants are CCP members and nearly all leadership positions are taken by CCP members, the civil servant disciplinary system was totally subsumed into the Party's CDI system.

Corruption is of course a crime and is investigated and prosecuted in the criminal justice system. Unlike other crimes which are investigated by the police, corruption, together with other offences committed by state functionaries in their official capacity, is investigated by the procuracy. A special branch called the "anti-embezzlement and bribery administration",

\footnotetext{
${ }^{6}$ For a succinct review of the history of CDIs, see Ting Gong, "The party discipline inspection in China: It evolving trajectory and embedded dilemmas" (2008) 49 Crime, Law and Social Change 139-152.

${ }^{7}$ Xiang Xu, Tan Suo: Zhongguo Gongchandang Jilü Jiandu Lun [Exploring: Disciplinary Inspection in the Chinese Communist Party) (Beijing: Central Party School Press, 2009).
} 
commonly referred in short as the "anti-corruption administration" (ACA), was set up within each procuracy to conduct anti-corruption investigation.

The relationship between CDI and ACA is not clearly set out. The CDI investigates misconduct of the CCP members and the ACA is the sole institution in charge of investigating the crime of corruption. Throughout the 1980s, both the CDIs and the ACAs worked side by side, cooperating and competing in anti-corruption matters. ${ }^{8}$ Since 1992 , however, the CCP, at its $16^{\text {th }}$ National Congress, decided that its CDIs should provide a leadership role in coordinating anti-corruption work in the nation. Following that particular instruction, the investigation of major corruption should be carried out directly by the CDIs with the cooperation and support of the ACAs. The CDI has a superior jurisdiction in anti-corruption. When an ACA is investigating a case and a relevant $\mathrm{CDI}$ has also started an investigation, the $\mathrm{ACA}$ is required to suspend its investigation pending the CDI investigation. Under CCP rules, any investigation of CCP officials of certain ranks must first be endorsed by the CCP Committee of the jurisdiction, a rule that suffocates any independent investigation of senior Party officials. Since the mid-1990s, the CCP's disciplinary mechanism has decisively appropriated anti-corruption enforcement in China. ${ }^{9}$

While the CDIs certainly play a leadership role in China's fight against corruption, their relationship with the ACAs and the ways in which they cooperate may vary. In major anticorruption investigation, ACA investigators are commonly seconded to CDI to assist with an investigation, together with the police and investigators from other government departments, even judges in certain cases. Out of a common investigation, the CDI and the ACA produce their respective documentations. The CDI prepares evidence for disciplinary action and the ACA would use the investigation to gather evidence for a possible criminal prosecution in the event the CCP opts for a criminal prosecution after the disciplinary action. There are also instances in which CDIs sent their investigators to the ACA to participate in or support an investigation initiated by the ACA.

While the political and legal anti-corruption bodies have their unique institutional advantage in anti-corruption investigations, the CCP leads or "interferes with" anti-corruption work, and law plays a limited role. The critical comments of Xiao Yang (肖扬), the then Chief Judge of the Supreme People's Court, well capture this particular relation of political dependence of legal institutions:

Some leaders are so used to the Party Committee approval system (in anticorruption investigation)... They interfere with case filing, investigation and decision-making; they give instructions, set perimeters and demand procuratorial organs to handle cases according to their opinions. When the procuratorial organs handle cases according to law and deviate from political instructions, they could

\footnotetext{
${ }^{8}$ Manion, note 1 above, at p. 133.

${ }^{9}$ Ibid., at p. 135.
} 
be reprimanded for "competing with the Party Committee", "objecting Party leadership", or even asked questions as absurd as "Who is more powerful, you the procuracy or me the Party Secretary?"10

This is a rhetorical question and the answer of which is well-known for all procurators. It is estimated that more than 80 per cent of the corruption cases are now firstly investigated by the CDI before the procuracy takes over if at all; for cases involving officials at xian/chu (县/处) level, more than 96 per cent of the cases are firstly investigated by the CDI; and for cases involving officials at sheng/bu (省/部) level, all of the cases are firstly investigated by CCDI. ${ }^{11}$ In the area of anti-corruption, it is well-accepted that political powers trump the law.

\section{The Party Norms}

The CCP has produced a wide range of soft law to guide its members. Those soft laws often list out behaviors that are unethical and in clear violation of the code for CCP members. Most of the behaviors are not ostensibly criminal and the line between corruption and some of the unethical behaviors are very thin with a large degree of overlapping. Those soft laws are comprehensive and have been circulating among the CCP members for decades. A random survey of the CCP disciplinary rules reveals that there are, at the ground level, rules prohibiting lavish living, womanizing, visiting prostitutes, practicing superstition, being religious, privilege-seeking, or violating the one-child policy; at the next level, there are rules against housing irregularities, unauthorized business operation, profiteering, or nepotism aiming at self-enrichment; and at the next higher level, there are rules against smuggling, irregular banking loans, misappropriation of public fund, and other types of financial fraud; and finally there are rules which replicate the existing criminal laws.

The greatest utility of the CCP rules is to cover the field so as to exclude the intrusion of external rules, including the criminal law. While criminal offence and disciplinary offence are conceptually distinct, there is a large overlapping jurisdiction in which the CCP norms prevail and can marginalize legal norms. Once the CCP defines an act or omission as misconduct without expressly authorizing criminal punishment, then criminal law is regarded as being ousted. For example, CCP rules govern and punish CCP members who use official funding for overseas travel for leisure, and as a result the abuse in that particular matter can only be a disciplinary matter and is not capable of becoming a criminal offence, no matter how abusive a case may be

\footnotetext{
${ }^{10}$ Xiao Yang, Fantan Baogao: Gongheguo Diyige Fantanwu Huilu Gongzuoju Dansheng de Qianqian Houhou [Anti-Corruption Report: The Birth of the First Anti-Corruption Administration in the Republic] (Beijing: Law Press, 2008), at p. 135.

11 Song Tao, "Anti-corruption is moving towards the CCDI Model" (2007(6)) Dangzheng Luntan [Party/Government Forum] 9.
} 
— the maximum penalty for this misconduct is dismissal from the CCP membership. ${ }^{12}$ The CCP norms are given priority in their application over legal norms. Legal rules are intentionally blocked so that the CCP has its own autonomy in disciplinary matters.

The fact that CCP norms prevail over legal norms does not necessarily mean that the former is a rational and well-designed regime. It is commonly observed that while there is a great quantity of rules, they are mostly of low quality. A major problem with the soft laws is their sporadic enforcement and the fact that they are mostly conspicuous by their violation. There is a lack of concrete institutional design and enforcement mechanism which could place compulsion on CCP members with any effectiveness. As it is openly conceded by the CCP itself, the CCP disciplinary rules are characterized by wide gaps and a large degree of flexibility and uncertainties. The rules are full with "prohibitions" but with no specification as to how prohibitions are to be enforced; they threaten "serious handling" for any violation of prohibitive rules but fail to specify the exact punishment that may be meted out for the violation. ${ }^{13}$

Given the lack of institutionalized enforcement mechanisms, it is not surprising that most of the soft laws are actually named as "self-investigation" (自查), “self-correction" (自纠) and "selfregulatory" (自律), and their enforcement relies largely on voluntary compliance. The enforcement of rules within the CDI regime relies largely on the imposition of moral standard and calling for the conscience of CCP members, or what Ting Gong calls "morality by decree", through which the CCP attempts to use CCP rules "as moral compass to guide its officials" and to prevent their moral decay. ${ }^{14}$

Examples abound. Every year the CCP circulates rules prohibiting $\mathrm{CCP}$ officials from receiving red packets and demanding officials to surrender the red packets they have received to the government. But the enforcement of the rules relies exclusively on voluntary compliance, though there is occasional superficial enforcement. There are also repetitive rules against banqueting at public expense, and to enforce those rules, some local authorities do not allow government cars to be parked within certain meters from designated restaurants. Of course, officials can always park their cars beyond the required distance and walk to the restricted areas. The Party is unable to take more effective measures such as publicizing entertainment budgets of government departments which may serve as a better deterrent against excessive official wining and dining.

\footnotetext{
12 "Officials' using of public fund for traveling overseas in violation of the law amounts to misappropriation of public funds", Guangzhou Ribao [Guangzhou Daily], 1 July 2010, available at Xinhuanet, <http://big5.xinhuanet.com/gate/big5/sd.xinhuanet.com/news/2010-07/01/content_20220029.htm> (Visited on 11 April 2011); "How to thoroughly prohibit traveling on public funds", Beijing Chenbao [Beijing Morning Post], 1 July 2010, available at Xinhuanet, <http://news.xinhuanet.com/politics/2010-07/01/c_12284875.htm> (Visited on 11 April 2011).

${ }^{13}$ Cui Changfa and Zhai Yongyuan, Fanfu Changlian Jianshe Xuexi Duben [Anti-Corruption Readers] (Beijing: State Institute of Administration, 2010), at p. 103.

${ }^{14}$ Gong, note 6 above, at p. 151 and "The Institutionalization of Party Discipline Inspection in China: Dynamics and Dilemmas," in Gong Ting and Stephen K. Ma (eds.), Preventing Corruption in Asia: Institutional Design and Policy Capacity (London: Routledge, 2009), Chapter 5.
} 
There is no shortage of rules against the operation of "mini-treasuries" (小金库) within government departments outside the official budgets, and campaigns have been launched frequently to crack down on such institutionalized abuses. A closer look at the enforcement, however, reveals that compliance is achieved largely through mere moral persuasion.

\section{The Disciplinary Mechanism}

The disciplinary regime is also a self-contained machinery. Numbering more than 350,000 members, which is about the size of China's judiciary and procuracy combined, the CDI system is a powerful empire. Politically, it is a powerful organ within the CCP Committee and has also the authority to discipline its members. As an essential part of the CCP rules, CCP members have the duty to obey the order within the CCP hierarchy. A CCP official may be able to show contempt to a legal institution, but $\mathrm{CCP}$ rules ensure that the official would follow $\mathrm{CCP}$ instructions.

The CCP maintains a comprehensive and apparently rigid disciplinary mechanism to discipline its members, with an equally impressive range of punishment applying to delinquent members, including, warning, serious warning, dismissal from CCP positions, retaining membership on probation, and expulsion from the CCP. Table 2 below is illustrative of the lenience that delinquent $\mathrm{CCP}$ members receive after a guilty finding.

Table 2: Breakdown of CCP Disciplinary Punishments Imposed (2005-2006) ${ }^{15}$

\begin{tabular}{|c|c|c|c|c|c|c|c|}
\hline \multirow[b]{2}{*}{ Year } & \multirow{2}{*}{$\begin{array}{c}\text { No. of } \\
\text { disciplinary } \\
\text { cases } \\
\text { concluded }\end{array}$} & \multirow{2}{*}{$\begin{array}{c}\text { No. of } \\
\text { persons } \\
\text { imposed } \\
\text { with CCP } \\
\text { disciplinary } \\
\text { punishment }\end{array}$} & \multicolumn{5}{|c|}{ Among the persons imposed with CCP disciplinary punishment } \\
\hline & & & Warning & $\begin{array}{c}\text { Serious } \\
\text { warning }\end{array}$ & $\begin{array}{l}\text { Dismissal } \\
\text { from CCP } \\
\text { positions }\end{array}$ & $\begin{array}{l}\text { Retaining } \\
\text { membership } \\
\text { on probation }\end{array}$ & $\begin{array}{c}\text { Expulsion } \\
\text { from the } \\
\mathrm{CCP}\end{array}$ \\
\hline 2005 & 148,931 & 115,143 & 44,836 & 32,289 & 3,171 & 10,657 & 24,188 \\
\hline 2006 & 122,777 & 97,260 & 37,434 & 27,185 & 2,744 & 8,777 & 21,120 \\
\hline
\end{tabular}

\footnotetext{
${ }^{15}$ Sources: "Work Report of the Central Committee of Disciplinary Inspection", 5 January 2006, available at Zhongguo Gongchandang Xinwen [News of the Communist Party of China], <http://cpc.people.com.cn/GB/64162/66215/4527710.html> (Visited on 11 April 2011); "Work Report of the Central Committee of Disciplinary Inspection", 8 January 2007, available at Zhongguo Gongchandang Xinwen [News of the Communist Party of China], <http://cpc.people.com.cn/GB/64093/64094/5401141.html> (Visited on 11 April 2011).
} 
A warning letter is the principal punishment for most CCP delinquents who otherwise would have been convicted of a criminal offence, had they been tried by a court of law. About 20 per cent were stripped of their CCP membership.

The CDIs also have all the powers that may be needed in carrying out investigations. The CDIs can search and seize premises and financial records, detain property and, as will be discussed below, hold suspects in detention for interrogation. A lack of clear legislative authority is never a concern for the CDIs in enforcing CCP rules. If legal justification is required, the CDIs can use the ACAs as a front organization to exercise legal powers - the ACAs are, politically speaking, one of the CCP's subordinate organs in the fight against corruption.

In addition, the CDIs also have extra-legal power, unconstrained by any law. The most drastic power is shuanggui (双规), a power to allow the CCP Committee to place a CCP member in detention for interrogation. ${ }^{16}$ Under shuanggui, a CCP member can be detained indefinitely without any contact with the outside world, and without any legal representation.

Modeled on the legal system, each CDI has a department to receive complaints, an operation department to carry out investigation and interrogation, and a trial department in charge of adjudicating cases and imposing penalties. The CCP disciplinary system is a well-structured system with clear division of labor among different working units within each CDI and among CDIs at different levels.

There are also well-developed internal procedures. To be sure, suspects have no legal rights because shuanggui is not regarded as a legal process - it is an internal disciplinary measure. Thus, appeal or review against any decision of the CDIs, even within the CCP disciplinary system, is not available, though there is a complicated interlocking approval procedure to ensure that a CDI's power is supervised by both the CCP Committee at the same level and the CDI at the next higher level.

The CDI system is a secretive system and the operation of the CDIs and that of the CCDI in particular remain mysterious. With legal rules being marginalized and legal professionals playing only a supporting role, transparency and publicity are unavailable within the disciplinary system. There is no duty to notify the family members of the persons put under shuanggui. Lawyers are barred from representing the suspects. The system is designed in such a way that the suspects in custody have to face the powerful CCP machinery without any assistance.

\footnotetext{
${ }^{16}$ Contrary to common perception, shuanggui has some statutory footing in the CCP rules and in the Administrative Supervision Law. Article 20 of the Administrative Supervision Law provides that: In investigating violations of the rules of administrative discipline, a supervisory organ may adopt the following measures in light of actual conditions and needs:
}

(3) to order the persons suspected of violating the rules of administrative discipline to explain and clarify questions relevant to the matters under investigation at a designated time and place; however, no such persons may be taken into custody or detained in disguised form; 
The CCP's in-house disciplinary mechanism serves as a clearance house to manage its corruption. As mentioned earlier, the CCP investigation is powerful, exclusive and secretive. The $\mathrm{CCP}$ alone decides whether an investigation is called for; limits the scope of the investigation when it is carried out; determines the degree to which legal institutions are to be involved, if at all; and makes decisions affecting the severity of punishment that the persons are to receive. Sapio has argued that shuanggui serves the dual functions "to avoid the shame that would be caused by a thorough investigation on corruption" to the CCP and to "channel the people's feelings of distrust and betrayals on carefully handpicked officials." 17 The CCP manages corruption cases according to political expedience and legal considerations are marginalized in the decision-making process. Most of the cases are internalized and ended with internal disciplinary action. Limited statistics shows that, among all the complaints substantiated and punishment imposed, a mere three to four per cent of the offenders were referred for criminal prosecution.

\section{The Upward Spiral}

The CCDI has received wide media attention in investigating high ranking CCP and government officials, including the recent high profile cases of Shanghai Party Secretary Chen Liangyu (陈良 宇) and Railway Minister Liu Zhijun (刘志军). National leaders are, so far, largely selfconstraining and have not been implicated in corruption scandals. This distinguishes China from other corruption-ridden countries, as China's national leaders are determined to act against corruption. But the CCDI may take an aggressive stance and go solo in anti-corruption enforcement because the CCP maintains a fragmented disciplinary system which faces a colossal problem of syndicated corruption. While the anti-corruption regime is CCP-led and CCPoperated, it is a largely fragmented one and there is an interlocking accountability within the CCP system.

China's authoritarian system is atypically decentralized with a division of power tilted towards local power centers. ${ }^{18}$ It is commonly accepted that China is able to achieve and sustain its economic growth largely due to its economic decentralization and competition among different regions within the country. Key economic decentralization includes the scrapping of central planning after 1992, and the subsequent devolution of economic and economic powers to localities in the areas of land, assets, personnel, loans and investments, tax liabilities, and rule compliance. Such decentralization, however, also leads to pervasive corruption.

Economic localization has significant political implications. Decentralization creates opportunities and incentives for developers, construction contractors, land speculators, and

\footnotetext{
${ }_{17}^{17}$ Flora Sapio, "Shuanggui and extralegal detention in China" (2008) 22(1) China Information 1-34, at p. 15.

${ }^{18}$ Pierre F. Landry, Decentralized Authoritarianism in China: The Communist Party's Control of Local Elites in the Post-Mao Era (Cambridge: Cambridge University Press, 2008).
} 
organized smugglers to offer bribes for lucrative projects. Localization also provides opportunities for local officials to pillage public resources directly. Central control over local corruption is limited. With few exceptions, a local CCP Committee is responsible for local economic growth and governance issues, and has control over a vast range of government departments, including CCP disciplinary organs, law enforcement organs, the prosecution and the court. Local CCP Committees monitor and discipline local officials without direct central involvement.

Under the CCP's current nomenklatura structure, a higher level CCP Committee appoints and monitors Party leaders at the next level. ${ }^{19}$ Thus, the CCDI has jurisdiction over cases committed by an official in the ranks of minister, vice-minister, provincial governor, and vice governor. In reality, the potential jurisdiction is wider. In investigating an official below the threshold rank, there is the potential that a higher rank official is implicated, and to bring the case against the higher rank official would invoke the authority of the CCDI. To be politically safe for the investigators and to act prudentially when acting against a high level official, provincial CDIs routinely report and refer cases to the CCDI for guidance and support. Local corruption, because of its scale and interconnectedness, becomes a national matter and can only be effectively investigated by the CCDI.

Research and reports in China have indicated that group corruption, that is a corruption scandal that involves a large number of officials, is now common, and the corruption syndicate extends horizontally to different departments at the same level. Smuggling scandals in Xiamen (厦门) and Jiangmen (江门) involved hundreds of middle ranking and senior CCP and government officials in each city; ${ }^{20}$ corruption in the City of Shenyang (沈阳) implicated almost the entire top echelon of the political and government departments; and a series of investigations of judicial corruption in Wuhan (武汉), Hunan (湖南), Guangdong (广东) and other places reveals that corruption in the courts often involved dozens of judges in the same court. More recently, an investigation in the City of Maoming (茂名) in Guangdong, led to the downfall of the City's Party Secretary, the Chairman of the Political-Legal Committee, two deputy mayors, and numerous officials in the City's political and legal establishment. ${ }^{21}$

More importantly, the network stretches vertically to higher levels. Just as organized crime syndicates seek official protection, corrupt officials seek protection from a higher level, to the

\footnotetext{
${ }^{19}$ Ibid. See also John P. Burns, "Strengthening Central Party Control of Leadership Selection, The 1990 Nomenklatura" (June 1994) 138 The China Quarterly 458-491.

${ }^{20}$ For examples of collective corruption in China, see Shawn Shieh, "The Rise of Collective Corruption on China: the Xiamen Smuggling Case" (2005) 14(42) Journal of Contemporary China 67-91.

${ }^{21}$ Zhong Wen, "Four Representatives' in Corruption in Maoming", Xin Bao [Hong Kong Economic Journal], 5 March 2011.
} 
effect that local investigation cannot be effectively initiated and continued by the CDIs. ${ }^{22}$ The most drastic change in China's corruption in the past decades is that money can purchase power from very high levels. Society and economic forces have incentives to take part in the decisionmaking process, and if they cannot influence decisions through votes, they can do so through bribes.

At the same time when corruption becomes more and more collective, it reaches the higher level CCP officials. There is a visible upward spiral - increasingly senior leaders are involved. ${ }^{23}$ Whether this means corruption is infecting the higher levels of government, or the government is now taking high level corruption more seriously, high level corruption is a fact and it presents serious difficulties to anti-corruption agencies.

Official figures show this changing landscape of corruption. Where CCP's in-house investigation and criminal prosecution have flattened over the past ten years or so, the number of prosecution that involved senior officials, or large and important cases, has actually increased. The litmus test is the number of officials at the levels of county magistrate or provincial governor. Between November 2007 and November 2008, for instance, among the 151,000 officials disciplined by the CDIs, 4,960 were at the xian/chu level or above. Between 1993 and 1997, there were only seven prosecutions against officials of the sheng/bu level, but the number increased to 35 between 2003 and 2007. ${ }^{24}$ As a CDI researcher noted recently, corruption among the top officials within a jurisdiction has increased quickly, ${ }^{25}$ a fact that the work reports of both the Supreme People's Court and the Supreme People's Procuratorate have demonstrated clearly. With the involvement of high ranking officials in corruption, the amount of money involved in corruption skyrockets and the latency - crime-capture lag — becomes much longer. ${ }^{26}$ Chart 3 is illustrative of the irony between the stability of the overall corruption prosecution and the increase in big and important corruption and bribery cases:

\footnotetext{
${ }^{22}$ Xiaogang Deng, Lening Zhang and Andrew Leverentz, "Official Corruption during China's Economic Transition: Historical Patterns, Characteristics, and Government Reactions" (2010) 26 Journal of Contemporary Criminal Justice 72-88.

${ }^{23}$ That is a trend that can be traced back to the 1980 s. See Manion, note 1 above, at p. 85 .

${ }^{24}$ Guo Cunliang, "Anti-corruption in the context of scientific development", Renmin Wang [The website of People's Daily], 11 December 2009, <http://unn.people.com.cn/GB/158820/158832/10564159.html> (Visited on 22 May 2011); Chen Xiao and Xu Kai, "Report on China's anti-corruption battle: 120 officials of provincial/ministerial level and above were removed in 23 years" (2011(3)) Shidai Youkan [www.shidaiyoukan.com], 29 March 2011, $<$ http://www.shidaiyoukan.com/xinwen/sdgz/2038.html> (Visited on 22 May 2011).

25 "Expert's interpretation: Corruption is turning from individual corruption to syndicate corruption; power, money, sex and triads are involved together", Wenhui Bao [Wen Wei Po], 12 March 2011.

${ }^{26}$ For a detailed discussion of the significance of a longer crime-capture lag, see note 2 above.
} 
Chart 3: Big \& Important Corruption \& Bribery Cases in China (1998-2009) ${ }^{27}$

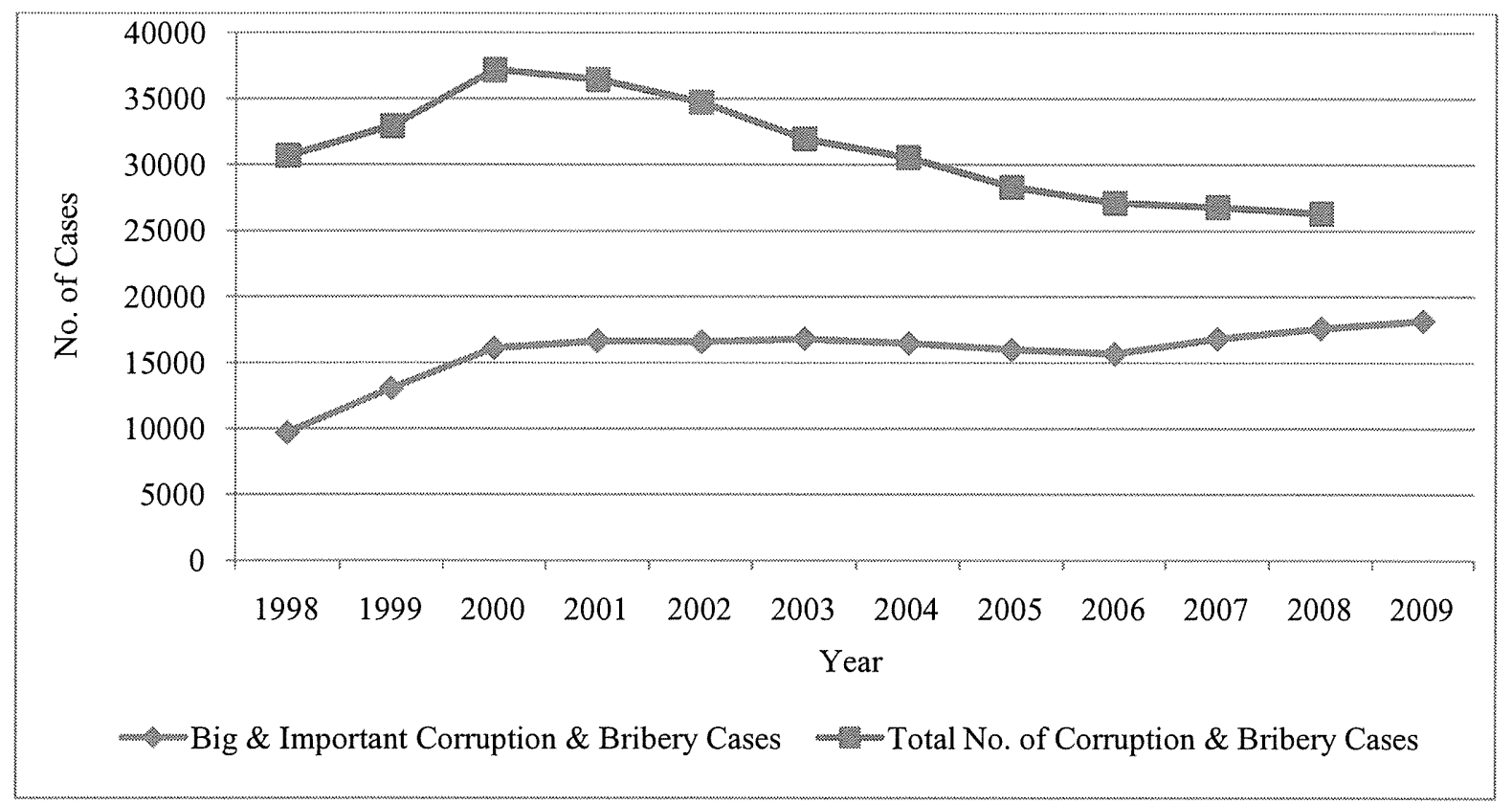

A major problem for the upward spiral relates to the political structure of the CCP. The CDI has a degree of independence since, as with the CCP Committee, its members are elected through the Party Congress. So it has a higher status than other working departments of the CCP. But the CCP Charter also makes it clear that the CDI works under the leadership of the CCP Committee of the same level, although CCP Committee's leadership over the CDI is shared with the CDI at the next higher level. There have been efforts in recent years to strengthen the vertical leadership among the disciplinary inspection system so that the local CDIs have a degree of independence from the respective local CCP Committees. ${ }^{28}$ However, despite the trappings of a more effective vertical accountability, all the evidence shows that the control by the CCP Committee at the local level is superior to that from the higher level CDI. The CCP openly admits that, because of the CDI's subordinate position within the hierarchy, the CDI is dependent, lacks of authority and cannot supervise the Party Committee to which the CDI is responsible. In many places, the CDI is almost a phantom organization. ${ }^{29}$ Gong argues that, "[a]s subordinates in the political hierarchy and with their appointment, promotion, and personal welfare virtually all controlled by leading cadres of local party committees, local CDI members face tremendous difficulties performing their supervisory duty independently." 30

Under the direct leadership of the local CCP Committee, the effectiveness of a local CDI depends on the support of the local CCP chief. It is commonly observed that the work of a CDI is

\footnotetext{
${ }^{27}$ Sources: Zhongguo Falü Nianjian [China Law Yearbook] (Beijing: Press of China Law Yearbook, 1999-2010).

${ }^{28}$ Gong, note 6 above, at p. 145.

${ }^{29}$ Cui and Zhai, note 13 above, at p. 102.

${ }^{30}$ Gong, note 6 above, at p. 150 .
} 
more effective and active where the CCP core is clean and serious about anti-corruption work. Where the political power corrupts at its core, as it is often the case in many jurisdictions, the CDI is ineffective at best. It could degenerate into a corruption institution aiding a corrupt political power. There is no shortage of examples where whistle-blowers are themselves placed under shuanggui or subject to other types of punishment, with the CDI playing the role of conspirator. $^{31}$

There is a visible process of centralization of power in the fight against corruption. In terms of enforcement, the CCDI has developed a standard set of procedures. Upon receiving complaints, the CCDI will dispatch investigators into a particular place to carry our investigation, under the protection of the military police, so that officials suspected of corruption would have little control over the investigative process.

Such cross-jurisdictional investigation is the standard modus operandi. The CDI in province A would be used to investigate corruption in province $\mathrm{B}$, and suspects may be detained in province C. The court which ends up in trying the cases may be from another different province. The case of the Shanghai Party boss, Chen Liangyu is an example. Chen was investigated by the CCDI, with the support of investigators from Jilin (吉林) and Jiangsu (江苏) provinces. ${ }^{32}$

The next step is to place the suspect officials under shuanggui, again in different places, to isolate them from the outside world. Once confessions are secured, the officials would be prosecuted and tried at different places. In 2003, the former governor of Yunnan (云南), Li Jiating (李嘉廷), was tried by a court in Beijing.

Given the syndicated nature of corruption involving powerful figures in a horizontal and vertical network, a proper investigation of a high profile case is costly and can only be possible when it is centrally-coordinated. Examples show that it takes approximately 49 investigators to investigate a ministerial level official and it may take more than 1,000 investigators in major cases, such as the smuggling cases in Zhanjiang (湛江) and Xiamen.

Investigation and prosecution of such syndicated corruption becomes extremely difficult for local enforcement, and local inertia in turn pushes more corruption cases upward to the provincial CDIs and the CCDI, thus creating an upward spiral.

\footnotetext{
${ }^{31}$ Wang Kean, "My opinion on 'Where is the Committee of Disciplinary Inspection"”, Renmin Wang [The website of People's Daily], 9 July 2004, available at Zhongguo Xuanju yu Zhili [China Elections \& Governance], $<$ http://www.chinaelections.org/NewsInfo.asp?NewsID $=51463>$ (Visited on 11 April 2011).

${ }^{32}$ The CCDI provides unique incentives for cross-jurisdictional investigation, prosecution and trial. Proceeds of the crime, usually large as mentioned above, are given to different parties involved as a reward.
} 


\section{The Downward Spiral}

When corruptive practice is pervasive in a locality or in an institution, the CDI's options are limited. Many of the pervasive forms of abuse of power may be regarded as corruption, but are politically tolerated or encouraged. The result is that this type of corruption is institutionalized and treated as legitimate in certain regions or certain sectors. Local governments in China throughout the 1990s, for example, collected illegal monies through fines, fees, levies or other means into their "mini-treasuries", defined as:

bank accounts, generally registered under false names, into which local governments, state agencies, and state-owned enterprises deposited illegal funds, including those obtained from illegal taxes, fees, fines, and apportionments; bribes paid to the institution; kickbacks, and budgetary and extra-budgetary funds diverted from legal accounts. ${ }^{33}$

Extra-budgetary fund is generated in part to meet public service requirements and in part to enrich the respective government departments and officials, often with the implicit endorsement by certain central institutions which also enjoy part of the benefits. ${ }^{34}$ When every government department is involved, the incentives to eliminate such institutionalized corruption can rarely come from localities which benefit from the very practices.

Most of these corruption cases, which may merit prosecution, are not prosecuted due to political concerns. Facing a collective corruption of colossal scale which may have infected a whole institution, it becomes politically challenging for the CCP to pursue the matter. Judicial corruption offers the best example. In Wuhan, judges bribed their superiors for promotion and the CCDI was aware of that fact after a thorough investigation. But it decided to leave most of the judges in their position for fear that any serious enforcement of anti-corruption in the City would necessarily mean the closure of many court houses - a result that can hardly provide legitimacy to the CCP. ${ }^{35}$ In 2010, an investigation related to the prosecution of disgraced VicePresident of the Supreme People's Court Huang Songyou (黄松有) exposed dozens of judges in various provinces who received bribes from lawyers. Most of the judges were allowed to continue to work in the same courts after being moved to support units.

It is now well known that, because of the direct involvement of the CCDI in major corruption cases, local CDIs' role has become less visible. As commentators have variously noted, the

\footnotetext{
${ }^{33}$ Andrew Wedeman, "Budgets, Extra-budgets, and Small Treasuries: Illegal monies and local autonomy in China" (2000) 9(25) Journal of Contemporary China 489-511.

${ }^{34}$ Ibid.

${ }^{35}$ Keith Henderson, "Corruption in China: half-way over the Great Wall, Transparency International, Global Corruption Report 2007 Corruption and Judicial Systems (Cambridge University Press, 2007).
} 
CCDI is conducting a solo show on the stage where corruption is fought, with local CDIs waiting and watching passively. Many argued that given the long latency in some of the corruption cases, it is unlikely that the local CDIs are not aware of the corrupt activities. Yet the local CDIs decided not to carry out any meaningful investigation of the matters, preferring to cooperate with the CCDI after the cases were reported to, and an investigation was initiated by, the CCDI. ${ }^{36}$ The heavy involvement of the CCDI in local corruption cases indicates the central government's determination against corruption as well as the local inertia.

At local levels, the number of prosecutions for corruption has declined. With their investigative powers limited, local CDIs and ACAs are targeting minor cases with little social impact or political significance, representing a downward spiral in China's fight against corruption. The irony in the anti-corruption enforcement is that, while corruption is perceived to be much more serious at local levels than that at the central level, ${ }^{37}$ enforcement against corruption is declining where it is most needed.

Where anti-corruption actions are taken by the local CDIs, the focus of their investigative work is shifting from organs at the core of the CCP power to the margins of the power, such as the educational sector, state-owned enterprises and other public authorities.

There are of course criminal punishment, but prosecution, conviction and sentencing play a symbolic role facilitating the CCP's anti-corruption rhetoric. There are high profile prosecutions, where the CCP has authorized the prosecution of CCP leaders of the highest rank, including members of its Political Bureau. In cases involving scandals that attract nation-wide attention, the harshest punishment - death with immediate execution - has been imposed. Routinely, the $\mathrm{CCP}$ uses these high profile cases to show-case its commitment to fight corruption.

An additional manifestation of the downward spiral is the leniency that corrupt local officials receive from local courts after conviction. Whatever objectives that the CCP intends to achieve through anti-corruption prosecution, deterrence is NOT one of them because at the end of the day, corrupt officials are treated with great leniency. A mere three per cent of the cases that are investigated by the CDIs are referred to ACAs for prosecution, and this low percentage has been surprisingly consistent over the years. Given the relative low threshold for corruption and perceived high rate of corruption, the CDIs must have blocked a large number of cases from further investigation and criminal prosecution.

The prosecution policy for corruption offences seems not to punish but to educate and rehabilitate. A prevailing view within the CCP is that, it is difficult to train a capable CCP official whose career should not be ruined merely because of corruption charges. As pointed out

\footnotetext{
36 "Expert: Local disciplinary inspection committees fail to duly fight against corruption", Wenhui Bao [Wen Wei Po], 17 November 2006, <http://paper.wenweipo.com/2006/11/17/CH0611170027.htm> (Visited on 11 April 2011).

${ }^{37}$ Lianjiang Li, "Political Trust and Petitioning in the Chinese Countryside" (2008) 40 World Politics 209-226. Jiangnan Zhu, Jie Lu and Tianjian Shi, "When Grapevine News Meets Mass Media: Different Information Sources for Perceptions of Government Corruption in Mainland China" (On file with the author).
} 
by Xiao Yang, who was instrumental in the creation of the ACAs within the procuracy, a significant part of anti-corruption work was educational and rehabilitative, making it a strongly policy-oriented task which emphasizes both principles and flexibility. He then cited "two onehalves" with support: only one half of the cases which were reported to and accepted by ACAs lead to criminal investigation; and only one half of cases investigated led to formal prosecution. The low percentage is less shocking than the tone of a leading anti-corruption official in China in endorsing the prosecution policy as serving certain educational and rehabilitative values.

For cases that are successfully prosecuted, the punishments are lenient reflecting a high level of general tolerance of crime. The conviction rate for corruption charges is high, even though the rate is slightly lower than the overall figure of all crimes. But the extreme leniency in punishment that corrupt officials received after conviction is striking. Chart 4 is a case flowchart for the investigation, prosecution and trial of offences committed by officials in their official capacities in $2004 .^{38}$ In that year, more than half of those convicted of corruption were allowed probation and the rate of probation is increasing. Adding together court decisions of exemption from criminal penalties, shorter term imprisonment which are effectively discounted by pre-trial detention, and medical parole that is easily granted for those who receive long term custodial sentence, the number of persons who actually serve a prison term after conviction of corruption must be small. The high percentage of non-custodial sentencing for corruption offence is not abnormal, however because non-custodial sentencing is in general on the increase across the board for all offences - it was 51.38 per cent in 2001 and increased to 66.48 per cent in $2005 .^{39}$ However, given the political significance that has been assigned to corruption, one must challenge the significance of anti-corruption investigation and prosecution if only a small percentage of CDI investigations leads to criminal prosecution and, even after conviction, vast majority of the corrupt officials do not spend a single day in prison.

The prosecutors have complained about the undue leniency in various occasions. Judges have their own difficulties. For example, confessions made to the CDI investigators are treated as evidence that the officials have surrendered themselves, a meritorious act which attracts sentence reduction. Convicted officials are still influential and courts are often facing political pressures to impose lenient sentence after conviction. The small number of corrupt officials who serve prison terms are treated separately from the general prison population and lead a "happy life" during imprisonment. ${ }^{40}$

\footnotetext{
${ }^{38}$ Between 80 to 90 percent of offences committed by officials in their official capacities are corruption offences. Zhongguo Falü Nianjian 2005 [China Law Yearbook 2005] (Beijing: Press of China Law Yearbook, 2005).

${ }^{39}$ It should be pointed out that the use of non-custodial sentences has been on the increase in general since the late 1990 s, even though the rate is about half of that for corruption offence. See Fu Hualing, "Institutionalizing criminal process in China," in Guanghua Yu (ed.), The Development of the Chinese Legal System: Change and Challenges (New York: Routledge, 2011), 26-48.

${ }^{40}$ The Chief Judge of Shenyang (沈阳) Intermediate People's Court, Jia Yongxiang (贾永祥), was sentenced to life imprisonment for embezzlement in 2001. According to a 2005 report, he "was leading a happy life" inside the prison, receiving visitors every day, hosting banquets and enjoying photos of nude ladies. He said in an interview that "I am
} 
Chart 4: Disposal of Offences by Officials in their Official Capacities in $2004^{41}$

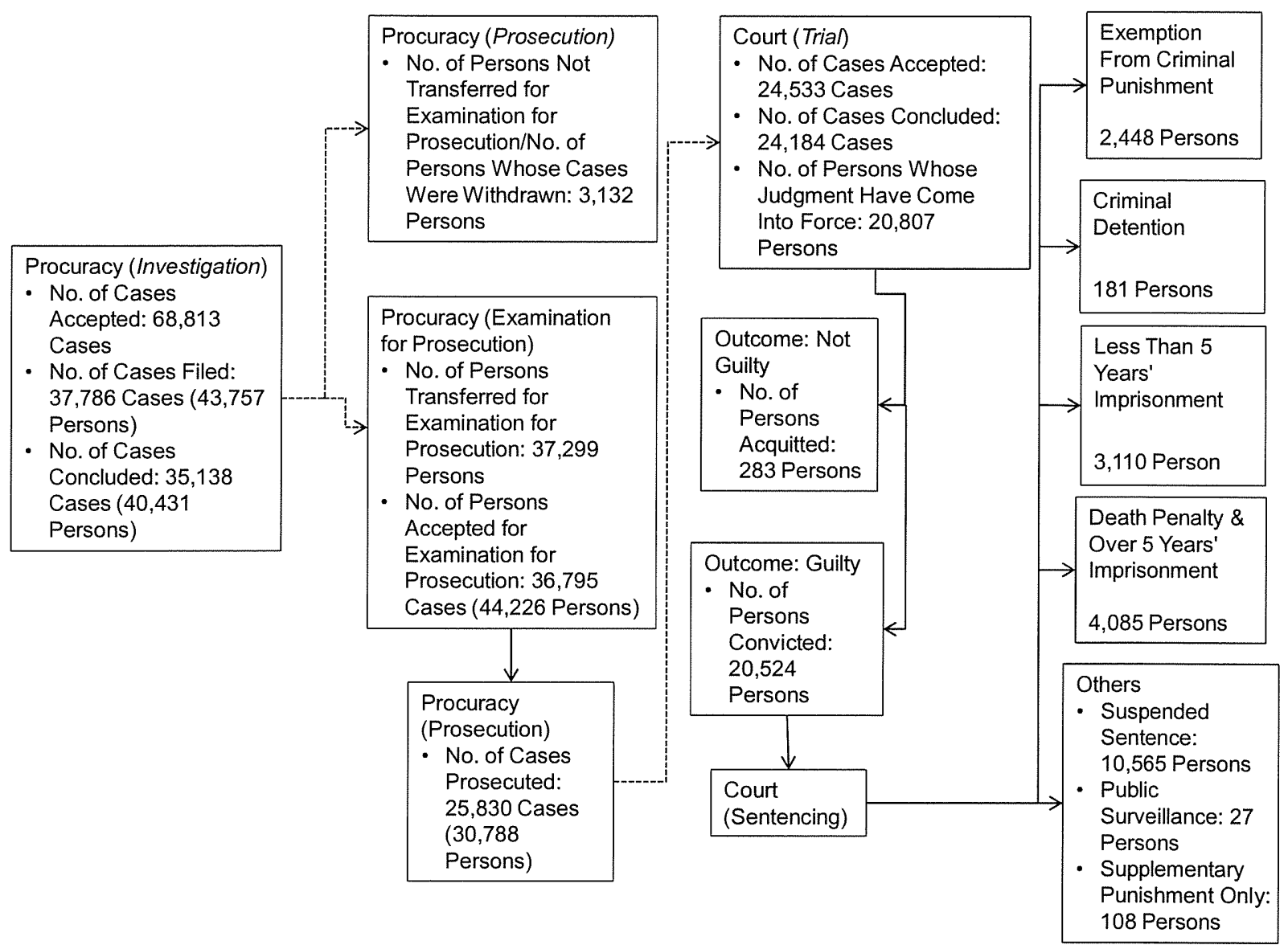

The CCP is aware of the fragile foundation and is taking various measures to strengthen the basic level institutions. In 2009, for the first time, the CCDI issued a document calling for the capacity building of county level CDIs, including a larger budget, better training and equipment. The CCDI also planned to increase the political status of a local CDI by enhancing the ranking of the

over 50 years old and there would be no chance enjoy life now if I don't do it now." See, "Quotations of Corrupt Officials - Speaking Out the Truth", Zhengyi Wang [jcrb.com], <http://review.jcrb.com/tgyds/index.htm $>$ (Visited on 22 May 2011).

${ }^{41}$ Source: Zhongguo Falü Nianjian 2005 [China Law Yearbook 2005] (Beijing: Press of China Law Yearbook, 2005). The cases that were investigated, prosecuted and tried in 2004 were not the same given the gap between the time of investigation and the time of sentencing (hence the dashed lines between investigation and prosecution and between prosecution and trial). I would like to thank Professor Ting Gong for pointing that issue out. But given the stability of corruption cases, the flow chart largely reflects the way that cases are disposed in the criminal justice system in a given year. 
CDI within the CCP hierarchy - by inviting a deputy chief of the CCP Committee to serve as the CDI head. ${ }^{42}$ There are many other top-down efforts to rejuvenate the local anti-corruption bodies, but given the root cause as identified in this paper, the current efforts can hardly arrest the advance of the two spirals.

\section{Conclusion}

Prosecution against corruption is a double-edged sword. Prosecution legitimizes the CCP by demonstrating its political will to fight corruption, but it also has the potential to undermine the legitimacy of the CCP by showing to the world that its institutions have rotted to their roots.

The upward and downward spirals reflect the difficulties of enforcing anti-corruption law in China in the past decade. Latency for corruption offences has become much longer; and corruption has become syndicated and often involves large number of officials in different government departments at different levels. As such, it is difficult for local anti-corruption bodies to initiate an investigation because of the syndicated nature of corruption, the involvement of a large number of officials, and the implication of powerful figures within the CCP system. A popular idiom is that the CCP would be finished if it were serious about anti-corruption. As argued forcefully by Wedeman, the leveling off shown by the flat lines in the above charts is misleading, corruption is getting much worse and the CCP may be losing the battle against corruption. $^{43}$

There may be a determined CCDI, supported by the CCP's Central Authorities, fighting uphill battles against corruption as evident in the frequent high profile investigations, prosecutions and punishment. But local corruption has become so entrenched while local anti-corruption bodies are losing their willingness and capacity. Without a meaningful participation of local anticorruption agencies, anti-corruption enforcement is unlikely to be effective.

With corruption becoming entrenched in the political establishment, what is the future of political corruption in China? This paper produces evidence for both the "gap" thesis and the "trap" thesis - corruption is out of control at local levels but the Central Authorities have prepared themselves and are ready to change. The future thus remains to be defined and options are wide open. Corruption may spread further into more regions and sectors and infect the political system more deeply. Scandals in Maoming may be commonly observed in other places with mini-Marcos or Suharto popping up in different localities in China. Judicial corruption as observed in many cities may become unstoppable. Monies in state banks are looted; offices are

\footnotetext{
42 "The Central Committee of Disciplinary Inspection strengthens the establishment of the local disciplinary inspection organs: Deputy Chief of the CCP Committee acting as the Secretary of the local disciplinary inspection committee", Renmin Ribao [People's Daily], 29 July 2009, available at Xinhuanet, $<$ http://news.xinhuanet.com/politics/2009-07/29/content_11789019.htm> (Visited on 11 April 2011).

${ }^{43}$ Wedeman, note 2 above.
} 
openly sold and officials send their families, and their loots, overseas. China will then go down the road of Indonesia under Suharto or the Philippines under Marcos as corruption further degenerates. $^{44}$

Alternatively, there is the possibility that the CCDI may eventually win the battle. To achieve that objective, the CCP must resort to help from without to fight the enemy from within. The CCP would need to open up the system and allow supervision from forces outside the CCP, including supervision from other political parties and civil society. It would also need to allow a large degree of freedom of the press and expression and an independent judiciary. There is enough internationally verified anti-corruption/governance practices for the $\mathrm{CCP}$ to learn - East Asia also provides ample successful models for China to emulate. It is just a matter whether the $\mathrm{CCP}$ is willing to take this step.

\footnotetext{
${ }^{44}$ Andrew Wedeman, "Looters, Rent-Scrapers, and Dividend-Collectors: Corruption and Growth in Zaire, South Korean, and the Philippines" (1997) 31 The Journal of Developing Areas 457-478; Pei, note 4 above.
} 